\title{
CS-19 - Una masacre en Nebaj, versión oficial, testimonios, doc- umentos de archivo y evidencia forense
}

\author{
A massacre in Nebaj, official version, testimonies, archival documents \\ and forensic evidence
}

Erwin Melgar

Universidad San Carlos de Guatemala y Área Forense, Centro de Análisis Forense y Ciencias Aplicadas, Guatemala

Autor al que se dirige correspondencia: erolmelvaz@yahoo.es

\section{Resumen}

$\mathrm{E}$ n la presente investigación se analizan sucesos ocurridos en una comunidad del municipio de Nebaj, departamento de Quiché, durante el conflicto armado interno en Guatemala (1960-96). El 16 de abril de 1981 en la aldea Cocop, por lo menos 73 pobladores fallecieron en circunstancias violentas. Según la versión oficial, las muertes ocurrieron de manera fortuita, durante un enfrentamiento entre miembros del Ejército Nacional y un grupo de insurgentes. Las víctimas de este hecho fueron enterradas en fosas comunes excavadas en terrenos de la aldea Cocop. En el año 2005, a solicitud de familiares de las personas fallecidas en este suceso, antropólogos forenses exhumaron los restos de las víctimas. Se recopiló información testimonial sobre los hechos ocurridos. Con técnicas arqueológicas se recuperó evidencia material en el sitio de entierro. En diferentes archivos se consultaron documentos relacionados con los sucesos violentos ocurridos en la aldea Cocop. En el año 2016 el Centro Estudios sobre Conflictividad Poder y Violencia localizó en archivos judiciales un documento con información sobre este evento. Los datos de las fuentes documentales, testimoniales y arqueológicas, se contrastaron con la versión oficial de los hechos. El análisis de la información recopilada, contradice la versión oficial y refuerza el relato testimonial de los sobrevivientes, quienes afirman que las víctimas fueron ejecutadas por miembros del Ejército Nacional.

Palabras claves: Conflicto armado interno, antropología forense, ejecuciones extrajudicales, represión, violencia política

\section{Abstract}

$\mathrm{T}$ he present investigation reports the events that occurred in a community of the municipality of Nebaj, department of Quiché, during the internal armed conflict in Guatemala (1960-96). On 16 April 1981 in Cocop village, at least 73 villagers died in violent circumstances. According to the official version, the deaths occurred incidentally, during a clash between members of the National Army and a group of insurgents. The victims of this fact were buried in mass graves excavated in lands of the Cocop village. In 2005, at the request of relatives of those killed in this event, forensic anthropologists exhumed the remains of the victims. Testimonial information about the events that occurred were collected. Using archaeological techniques, material evidence was recovered at the burial site. In different archives, documents related to the violent events in Cocop village were consulted. In 2016, the Center for Conflict Studies Power and Violence, located in court archives, a document with information about this event. The data of the sources, documentary, testimonial and archaeological, were contrasted with the official version of the facts. The analysis of the information compiled contradicts the official version and strengthens the testimonial version of the survivors, we affirm that the victims were executed by members of the National Army. 